\title{
PECULIARITIES OF THE SELF-CONCEPT IN STUDENTS WITH SPECIFIC LEARNING DISABILITIES
}

\author{
Maya Fyodorova-Radicheva ${ }^{1}$
}

\begin{abstract}
Specific learning disabilities (SLD) in adolescence are a key area for the successful application of the principles of integrated education. However, there are not many studies on the topic, which is a key indicator of the relevance of this study. The study presented in this article aims to detect and analyze the presence of characteristic features in the concept of self in students with SLD in middle school age (from 10 to 16 years of age). In order to establish characteristic features and peculiarities, an adapted version of the Q-sorting methodology was used. This method includes sorting cards with 14 polar personal traits, selected for their accessibility and distinctness for students with SLD. A total of 32 students in secondary schools in the municipality of Plovdiv were studied. 16 of them without a history of disabilities, and the remaining 16 have already been diagnosed with SLD, for which they receive special additional support in the schools where they study. The results show the presence of distinctive and specific differences in some aspects of the self-concept. The most significant differences are in the appraisal of the qualities "Capable", "Clever" and "Silly". The first two qualities are assessed by the students with SLD as less relevant to their real-self, and the third is assessed as much more relevant to their own self-image, in contrast to their classmates without disabilities. This assessment does not show gender or age specifics.
\end{abstract}

UDC Classification: 159.97, DOI: https://doi.org/10.12955/pss.v2.209

Keywords: specific learning disabilities, SLD, self-image, dyslexya

\section{Introduction}

Specific learning disabilities (SLD) are part of the complex of disorders that underlie the emergence of specific educational needs (SEN). Although not a common disorder, it is a particularly pressing problem due to the need to develop uniform methodologies for research and therapeutic activities that can be introduced into the education system. Creating a unified model of working with the construct is always a problem associated with conducting a number of studies and analysis of a wide range of factors influencing the studied problem. In the modern model of integrated education, children with SEN are placed in a peer environment, predominantly, without any difficulties and should acquire the skills and knowledge set in the main school curriculum. They don't just learn, but also develop their personality in school. Along with all the benefits of this type of communication and learning, there may be negative effects caused by the competitive, at times, nature of schooling and the inability of students with SLD to acquire some knowledge and skills with the speed and completeness with which their classmates cope. This aspect of the problem in most studies remains somewhat out of the picture, as its connection with the development of the social aspects of the individual and its internal congruence remain a poorly explored field in the psychological spectrum. Therefore, the present work focuses on this social perspective, looking for possible points of contact between the disorder and the formation of self.

\section{Literature review}

Literature behind this article is focused on the two main dimensions of the problem. On one hand, SLD and their specifics, and on the other, the formation and development of the self-image in this age.

\section{Specific Learning Disabilities}

"Specific learning ability" (SLD) is not a single disorder, but an umbrella term that includes disorders in the acquisition of various specific school skills - reading, writing, ability to perform arithmetic operations and work with nonverbal, abstract information (NJCLD, 2018). The most important criteria determining the existence of such a disorder are: the discrepancy between the learning potential of the student and the current level of learning, in the presence of adequate education (Levterova, 2005); the presence of reduced (according to age) reading, writing and arithmetic skills, while "their abilities in other areas give reason to expect more from them" (Matanova, 2003); the absence of other (sensory, intellectual, emotional) disorders (Levterova, 2005); intra-individual origin of the impairment; language disorders, academic underachievement (Hammil, 1990); (partial) retardation, which is described as the immaturity of certain functions and aspects of the psyche (Sorokin, 2003); and minimal dysfunction in the central nervous system. The presence of minimal brain dysfunction causing SLD is suggested by all of the above-mentioned researchers. Transmodal gnosis (rhythmic) can also be affected, and tempo, melody, beat patterns, and rhythm are not always well discriminated from both verbal and nonverbal

\footnotetext{
${ }^{1}$ Plovdiv University “Paisii Hilendarski”, Faculty of Pedagody, maya.fyodorova@uni-plovdiv.bg
} 
stimulus (Levterova et al., 2018). Quite often these students have some problematic behavior, reduced strength and duration of attention, a lower work efficiency compared to their peers. At the same time, without having intellectual problems, they lag behind in mastering and especially in memorizing the material, but they do not show only signs of dyslexia (Prishchepova, 2019). Gribanov and Risina (2011) point to a tendency towards a slower and more inaccurate response to newly given stimulus compared to other children. They also found a need for more time to make decisions, which they suggest is due to a delay or difficulty in perceptions or in the afferent synthesis in the processing of information. These characteristics are also pointed out by Passolunghi (2011), obtained from a similar study of students with impaired mathematical skills. The slower speed of information processing, weaker verbal memory, more procedural errors, and impulsivity are some of the results obtained from this study. We also report difficulties in screening and ignoring the irrelevant for the given task information. This has been indicated as a possible reason for the occurrence of the above-mentioned peculiarities. Greater impulsivity in children with SLD is also reported by Venkatesan and Lokesh (2019). This personal trait complex mentioned by many researchers brings to light questions about the social dimensions of SLD.

Social aspects of SLD and image of self

As Ruegg (2006) points out, children with SLD have low self-esteem, demoralization, and deficits in social skills. In addition, social deficits can arise as a result of some disorders that are common among children with this type of disorder - depression, oppositional deviant disorder, hyperactivity disorder and attention deficit. Kevan (2003) also draws attention to this phenomenon by providing evidence in favor of the link between communication difficulties and challenging behavior. He found an inverse relationship between communication skills and challenging behavior. At the same time, there is a certain heterogeneity - some children show negativity and do not want to initiate social contacts, others try but fail to maintain communication or are hyperactive in their speech behavior (Levterova, Atanasova, \& Trichkov, 2016). In general, it can be argued that social intelligence in children with dyslexia is hampered mainly because "the operations with semantic content presented in verbal form is impaired" (Kiseleva, 2011). The existence of a positive correlation between social intelligence and learning skills has also been pointed out by Kaukiainen et al. (2002). They describe higher levels of aggression in the behavior of children with SLD. The peculiarities in social functioning of the students with SLD affect the formation of their personality, especially in the age group considered in the present paper of 10-16 years, when the development of identity is marked by the crisis of identity against confusion. As Eriksŭn (2013) points out, adolescents at this age are "unusually engaged in what they seem to represent in the eyes of others compared to what they themselves feel they are." This unusually strong commitment is also at the heart of the construction of mature identity in adolescents, which "always takes place in a specific cultural field" and through the "exchange of significant symbols" that provoke emotions in both the individual and the social group where its development takes place (Popzlateva, 2010). In this context, social relations and social comparison play a significant role in the formation of identity in this age group. By definition, students with SLD have predetermined lower academic achievements, compared to their peers. The presence of deficits in the acquisition of school skills presupposes a certain lower academic success in relevant, determined by the deficit type, subjects. This suggests that the considered group: students with SLD, at the age of puberty (10-16 years) will face an almost certain negative factor (low academic performance) in building their identity. This supposes that for students with SLD the social comparison mechanism does not act in their favor. The search for a solution to identity crisis in this specific group, as is for the others should not be done without analyzing the resolution of previous crises. But the resulting identity embodied in the overall, integrated and coherent self-image can be considered final, at least for the current period of development. The product of the positive solution to the current crisis of identity development is to overcome the confusion of roles. In fact, this concept is valid for all other students, but for those with SLD it can be extremely important because they generally have more difficulties in forming a congruent and coherent self-concept. The presence of such a trend in students in the considered age group (lower rate of formation of image of self) is also indicated by Gallagher et al. (2020). The listed characteristic of SLD give grounds to search for specifics in the selfimage through a study based on the principles of the Q-sorting method.

\section{Data and methodology}

The methodological principles and mathematical justification of the Q-sorting method were developed in 1953 by William Stephenson (Bardov, 2008). The potential of the method was noticed by Carl 
Rodgers who began to use it extensively to study the self-image. The basis of the methodology for the study of the images of real and ideal-self, through this type of sorting is laid, namely by him. He suggested that the lack of a strong correlation (the presence of large discrepancies) between the two images showed poor adjustment and unrealistic self-esteem (Kaplan, R. Sakŭzo, D., 2013). The improvement of the coherence indicator is perceived by the author as a good measure of the improvement of "social adjustment skills" (Rogers, 2018). The classical methodology was adapted for the present study. The adaptation is based on the Bulgarian adaptation of Kokoshkarova (1984). In her study, she used the methodology of Rogers (1954), adapted in short form by Helm (1977) to study the characteristic coherence of the image of self in "neurotically ill". In this methodology 28 statements are used,14 positive and 14 negative, and they are sorted into 6 categories. In the current revision of the instrument, the reduction of the sorting categories is done in order to preserve the quasi-normal distribution of the obtained data, necessary for the application of the statistical technique of processing the final result. Taking into account the characteristics of students with SLD in the current adaptation the sorted items are reduced to half - up to 14 (7 positive and 7 negative), and the categories to 5 . Given the psychological characteristics of the subjects, sorted statements are significantly simplified by introducing simpler linguistic constructions. Sorted statements are polar to facilitate self-assessment.

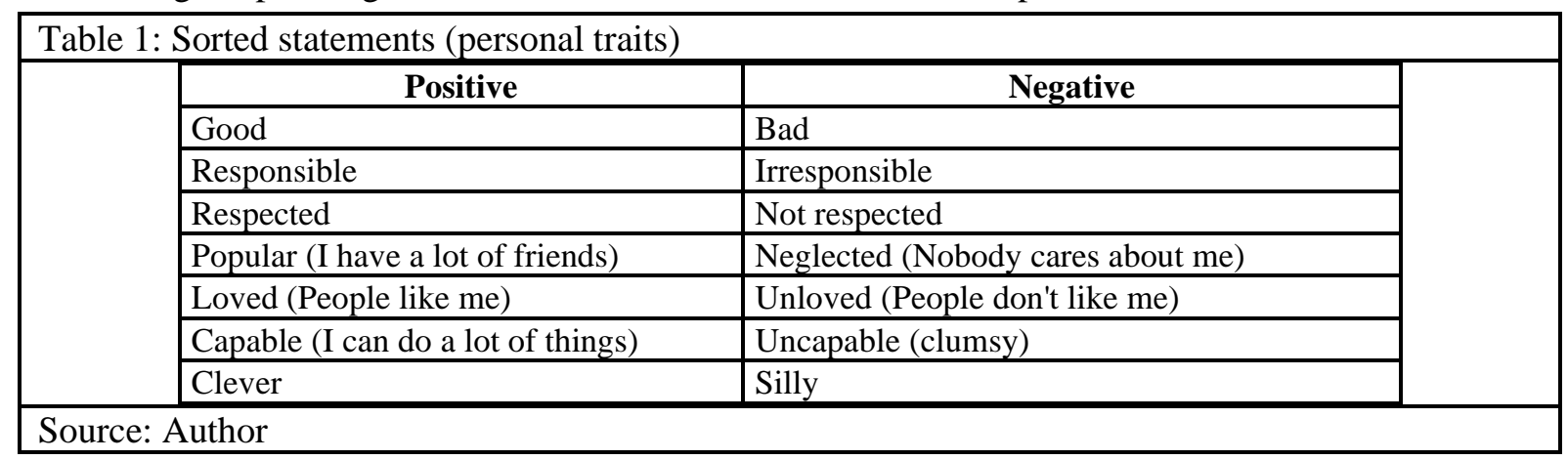

\begin{tabular}{|c|c|c|c|c|c|c|c|c|c|c|c|c|c|c|}
\hline Subject & Good & $\begin{array}{l}\text { Respo- } \\
\text { nsible }\end{array}$ & $\begin{array}{l}\text { Resp- } \\
\text { ected }\end{array}$ & $\begin{array}{l}\text { Popu- } \\
\text { lar } \\
\end{array}$ & \begin{tabular}{|l} 
Lov- \\
ed
\end{tabular} & $\begin{array}{l}\text { Cap- } \\
\text { able }\end{array}$ & $\begin{array}{l}\text { Cle- } \\
\text { ver }\end{array}$ & $\mathrm{Bad}$ & $\begin{array}{l}\text { Irresp- } \\
\text { onsible }\end{array}$ & $\begin{array}{l}\text { Notres- } \\
\text { pected }\end{array}$ & \begin{tabular}{|l} 
Negl- \\
ected
\end{tabular} & $\begin{array}{l}\text { Unl- } \\
\text { oved }\end{array}$ & $\begin{array}{l}\text { Unc- } \\
\text { apable }\end{array}$ & Silly \\
\hline 1 & 4 & 4 & 2 & 3 & 5 & 3 & 4 & 2 & 1 & 3 & 2 & 1 & 5 & 3 \\
\hline 2 & 5 & 5 & 3 & 3 & 4 & 3 & 4 & 4 & 1 & 2 & 1 & 2 & 3 & 2 \\
\hline 3 & 5 & 3 & 3 & 2 & 5 & 1 & 2 & 3 & 4 & 3 & 1 & 2 & 4 & 4 \\
\hline 4 & 4 & 3 & 4 & 1 & 2 & 3 & 2 & 3 & 4 & 5 & 5 & 1 & 2 & 3 \\
\hline 5 & 5 & 1 & 3 & 1 & 5 & 3 & 2 & 3 & 4 & 4 & 4 & 2 & 2 & 3 \\
\hline 6 & 5 & 4 & 5 & 3 & 3 & 4 & 4 & 3 & 3 & 2 & 1 & 2 & 1 & 2 \\
\hline 7 & 5 & 3 & 2 & 5 & 3 & 3 & 3 & 1 & 4 & 4 & 4 & 2 & 2 & 1 \\
\hline 8 & 4 & 5 & 2 & 3 & 3 & 4 & 3 & 1 & 2 & 4 & 1 & 2 & 3 & 5 \\
\hline 9 & 3 & 3 & 4 & 5 & 5 & 3 & 4 & 1 & 1 & 2 & 2 & 2 & 4 & 3 \\
\hline 10 & 5 & 5 & 4 & 4 & 4 & 3 & 3 & 3 & 1 & 2 & 1 & 2 & 2 & 3 \\
\hline 11 & 4 & 4 & 5 & 2 & 5 & 4 & 3 & 3 & 1 & 3 & 2 & 2 & 3 & 1 \\
\hline 12 & 2 & 4 & 3 & 5 & 4 & 3 & 2 & 1 & 2 & 3 & 1 & 4 & 5 & 3 \\
\hline 13 & 5 & 4 & 4 & 3 & 4 & 5 & 3 & 1 & 3 & 2 & 2 & 1 & 2 & 3 \\
\hline 14 & 5 & 4 & 3 & 2 & 4 & 4 & 3 & 2 & 5 & 3 & 2 & 1 & 3 & 1 \\
\hline 15 & 5 & 5 & 4 & 2 & 4 & 4 & 3 & 1 & 2 & 3 & 3 & 3 & 2 & 1 \\
\hline 16 & 2 & 1 & 1 & 2 & 2 & 4 & 3 & 4 & 3 & 5 & 5 & 4 & 3 & 3 \\
\hline
\end{tabular}

The statements are sorted into the following categories: "This does not apply to me at all" (2 cards); "This applies to me in parts, to some extent, approximately" ( 3 cards); "This already applies more to me" (4 cards); "This is very important to me" ( 3 cards); "This applies exactly to me" ( 2 cards). When placing a statement in a category, a relative score between 1 and 5 it is assigned. Starting with 1 point for a statement placed in "This does not apply to me at all" to 5 points for "This applies exactly to me". The subjects arrange the cards with personal traits (statements) according to their perceived relevance to the answer to the question: "Who am I?" (Rogers, 2018). This is considered as a description of the real-self of the subjects. With the present methodology 32 students were studied from 17 different schools in Plovdiv, Bulgaria. 16 of them were diagnosed with SLD and 16 were without a history of 
disorders. The average age of the subjects is 13.06 years (min. 10 and max.16). 17 boys and 15 girls. All the data was collected between September 2019 and March 2020 with the explicit consent of both the students, their parents and the supporting pedagogical professionals (psychologists, speech therapists, resource teachers). The results from the research are shown in Table 2 and 3.

\begin{tabular}{|r|l|l|l|l|l|l|l|l|l|l|l|l|l|l|}
\hline Table 3: Results Students without SLD \\
\hline Subject & Good & $\begin{array}{l}\text { Respo- } \\
\text { nsible }\end{array}$ & $\begin{array}{l}\text { Resp- } \\
\text { ected }\end{array}$ & $\begin{array}{l}\text { Popu- } \\
\text { lar }\end{array}$ & $\begin{array}{l}\text { Lov- } \\
\text { ed }\end{array}$ & $\begin{array}{l}\text { Cap- } \\
\text { able }\end{array}$ & $\begin{array}{l}\text { Cle- } \\
\text { ver }\end{array}$ & $\begin{array}{l}\text { Irresp- } \\
\text { Bad } \\
\text { onsible }\end{array}$ & $\begin{array}{l}\text { Notres- } \\
\text { pected }\end{array}$ & $\begin{array}{l}\text { Negl- } \\
\text { ected }\end{array}$ & $\begin{array}{l}\text { Unl- } \\
\text { oved }\end{array}$ & $\begin{array}{l}\text { Unc- } \\
\text { apable }\end{array}$ & Silly \\
\hline 1 & 5 & 5 & 3 & 3 & 1 & 4 & 4 & 3 & 4 & 3 & 2 & 2 & 1 & 2 \\
\hline 2 & 3 & 4 & 5 & 3 & 3 & 4 & 4 & 3 & 2 & 2 & 1 & 2 & 5 & 1 \\
\hline 3 & 3 & 4 & 3 & 3 & 5 & 4 & 4 & 3 & 2 & 5 & 1 & 2 & 2 & 1 \\
\hline 4 & 5 & 1 & 2 & 3 & 2 & 3 & 3 & 4 & 5 & 4 & 1 & 2 & 3 & 4 \\
\hline 5 & 4 & 3 & 4 & 5 & 4 & 3 & 5 & 3 & 3 & 2 & 1 & 2 & 2 & 1 \\
\hline 6 & 5 & 3 & 4 & 1 & 4 & 3 & 4 & 3 & 5 & 1 & 2 & 3 & 2 & 2 \\
\hline 7 & 5 & 3 & 4 & 4 & 3 & 4 & 5 & 1 & 2 & 3 & 3 & 2 & 2 & 1 \\
\hline 8 & 3 & 3 & 4 & 4 & 3 & 5 & 5 & 1 & 2 & 4 & 2 & 2 & 3 & 1 \\
\hline 9 & 4 & 3 & 3 & 5 & 4 & 4 & 5 & 2 & 3 & 3 & 1 & 2 & 2 & 1 \\
\hline 10 & 3 & 4 & 5 & 5 & 3 & 4 & 3 & 4 & 2 & 1 & 2 & 1 & 2 & 3 \\
\hline 11 & 5 & 3 & 3 & 4 & 5 & 4 & 3 & 3 & 4 & 2 & 1 & 1 & 2 & 2 \\
\hline 12 & 4 & 4 & 4 & 3 & 3 & 5 & 5 & 3 & 2 & 2 & 2 & 3 & 1 & 1 \\
\hline 13 & 3 & 3 & 4 & 4 & 4 & 5 & 5 & 3 & 3 & 2 & 1 & 2 & 1 & 2 \\
\hline 14 & 5 & 5 & 4 & 3 & 3 & 4 & 4 & 1 & 2 & 3 & 3 & 2 & 2 & 1 \\
\hline 15 & 5 & 2 & 3 & 3 & 5 & 4 & 4 & 3 & 4 & 2 & 1 & 2 & 3 & 1 \\
\hline 16 & 5 & 5 & 3 & 2 & 4 & 4 & 4 & 3 & 1 & 3 & 1 & 2 & 3 & 2 \\
\hline Source: Author
\end{tabular}

\section{Results and discussion}

The points indicated for every sorted card are attributed depending on the category where the subject choose to sort them as mentioned above.

In order to look for possible specifics, expressed in statistically significant differences between the results obtained from the comparative study of students with SLD and those without, was performed ANOVA analysis. For the analysis was used IBM SPSS Statistics Version 25.

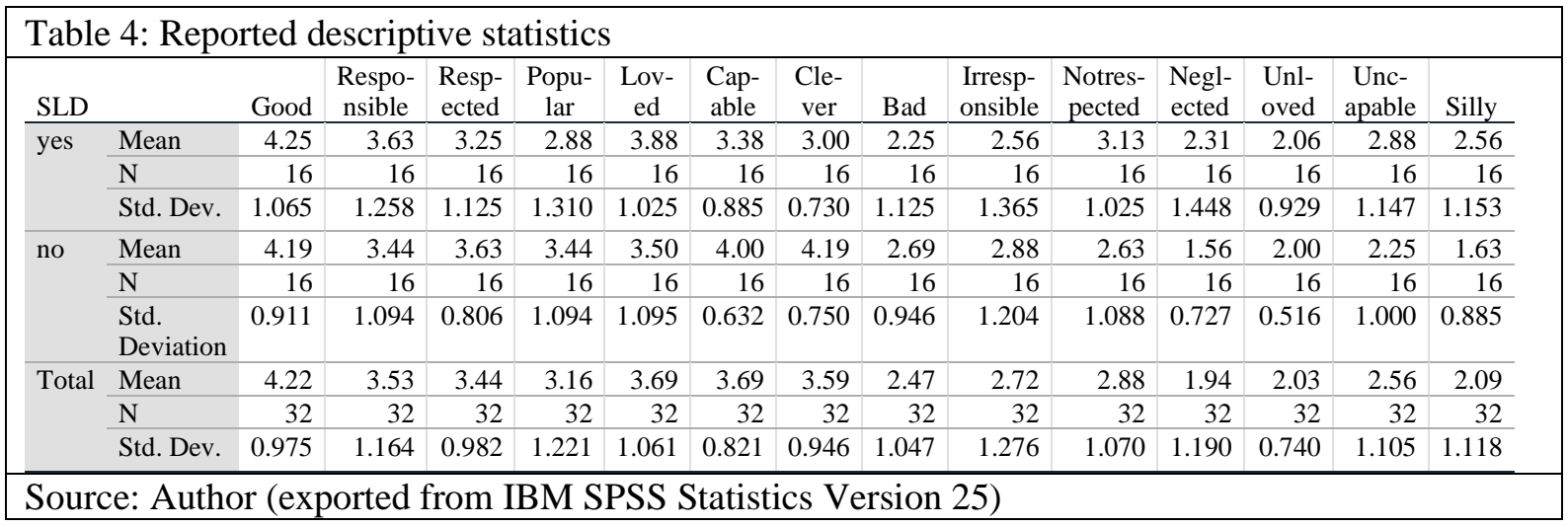

As expected, the positive statements have a higher average value of indicators. The highest is for the trait "Good" - 4.25 points for students with SLD and 4.19 for students without SLD. For students in the norm, the average value for this trait is the same as that for the quality "Clever". This personal trait for students with SLD registers the second lowest result of the positive qualities (3.00 points). The lowest score for students with SLD is for "Unloved" (2.06), and for students in the norm "Neglected" (1.56).

An ANOVA analysis revealed statistically significant differences between the values of the arithmetic mean of 3 sorted personal traits. From the positive personal qualities "Capable (I can do many things)" and "Clever" show significant difference between the two groups. From the sorted negative personal traits only "Silly" showed significant difference in the mean value between the studied groups. The results for the rest of the sorted personal traits, which didn't show statistically significant differences (Sig.> 0.05) are not shown in the Table 5.

The value of the average grade for the traits "Capable" and "Clever" in students without disabilities is significantly higher than that in students with SLD. The mean for the trait "Capable" for students with 
SLD is 3.38 point, compared to 4.00 point for those without disabilities. For the second personal trait "Clever" the difference is ever bigger - 3.00 points average for students with SLD and 4.19 for those without. In other words, students without disabilities value their cognitive skills and manual dexterity more than those with SLD.

\begin{tabular}{|c|c|c|c|c|c|c|c|}
\hline \multicolumn{2}{|c|}{ ANOVA Table } & \multicolumn{6}{|c|}{$\begin{array}{l}\text { Table 5: Comparing means (Only rows with statistically significant difference shown) 95\% } \\
\text { Confidence Interval of the Difference }\end{array}$} \\
\hline & & & $\begin{array}{l}\text { Sum of } \\
\text { Squares }\end{array}$ & df & Mean Square & $\mathrm{F}$ & Sig. \\
\hline \multirow{3}{*}{$\begin{array}{l}\text { Capable * } \\
\text { SLD }\end{array}$} & Between Groups & (Combined) & 3.125 & 1 & 3.125 & 5.282 & 0.029 \\
\hline & Within Groups & & 17.750 & 30 & 0.592 & & \\
\hline & Total & & 20.875 & 31 & & & \\
\hline \multirow{3}{*}{$\begin{array}{l}\text { Clever * } \\
\text { SLD }\end{array}$} & Between Groups & (Combined) & 11.281 & 1 & 11.281 & 20.589 & 0.000 \\
\hline & Within Groups & & 16.438 & 30 & 0.548 & & \\
\hline & Total & & 27.719 & 31 & & & \\
\hline \multirow{3}{*}{$\begin{array}{l}\text { SIlly * } \\
\text { SLD }\end{array}$} & Between Groups & (Combined) & 7.031 & 1 & 7.031 & 6.657 & 0.015 \\
\hline & Within Groups & & 31.688 & 30 & 1.056 & & \\
\hline & Total & & 38.719 & 31 & & & \\
\hline
\end{tabular}

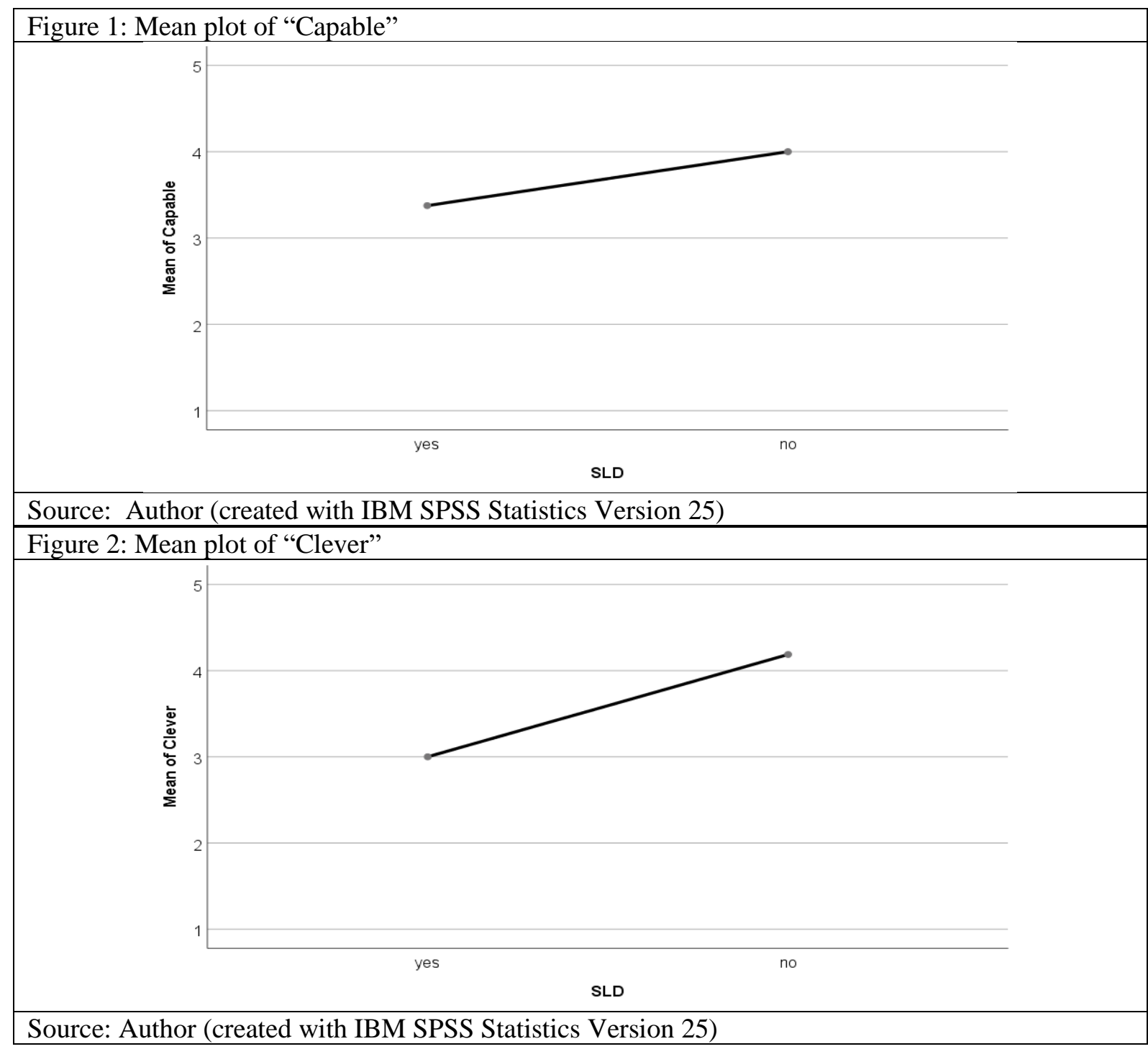

On the other hand, there is a significantly higher value in the average assessment of the relevance to the personality of students with SLD with the trait "Silly". The students without disabilities gave a mean grade of 1.63 points and the students with SLD 2.56. 


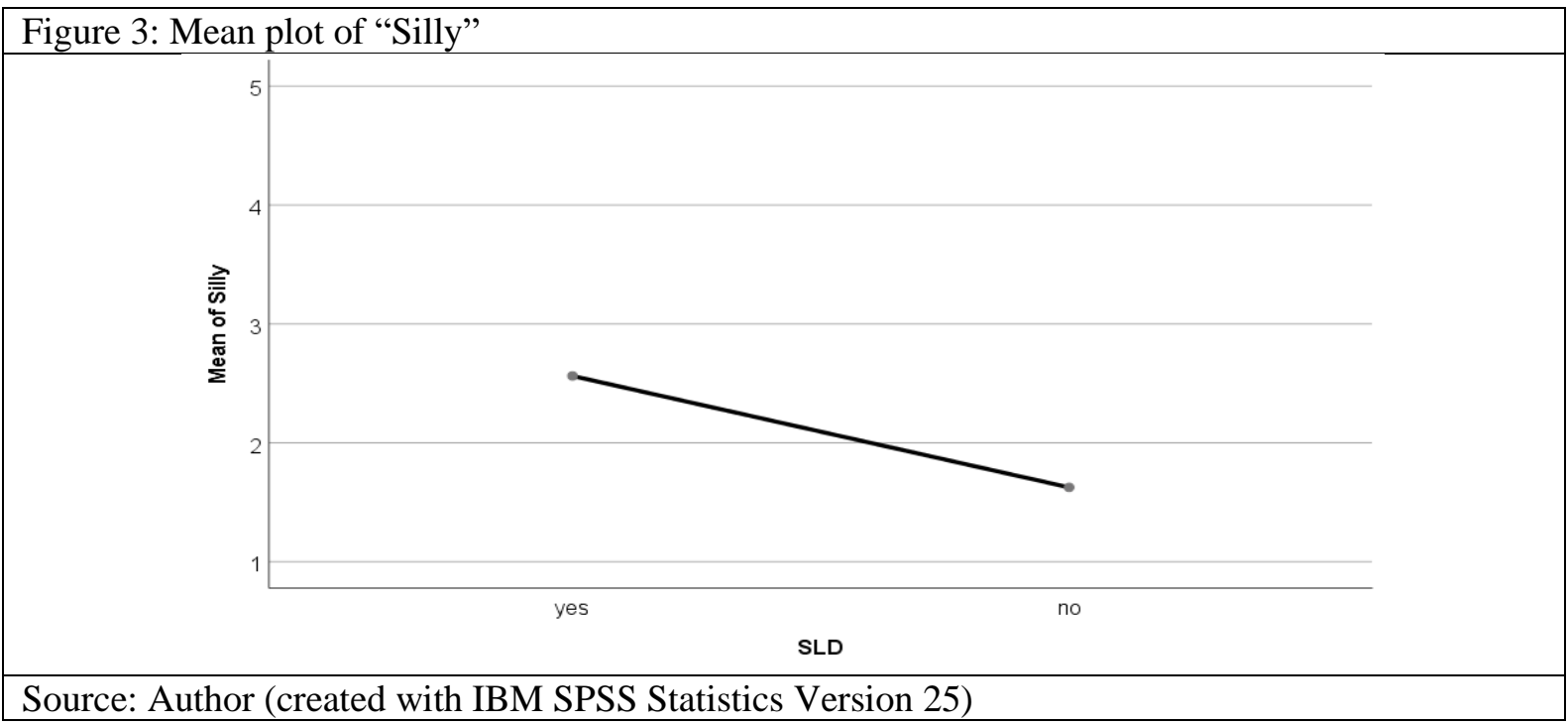

This conclusion completes the picture so far, reinforces the notion that students with SLD rate their cognitive abilities significantly lower. This confirms the assumption of the importance of social comparison in the formation of the self-image and gives reason to believe that the difficulties in acquiring school skills have a particularly strong impact on the self-esteem of students with SLD.

\section{Conclusion}

This kind of lower assessment of abilities can lead to a decrease in learning motivation, which is one of the main factors for success in school education. This necessitates an in-depth study of the roots of this perception and in directing the methodologies and therapeutic work with students that have SLD to increase their motivation to learn and to compensate for their feelings of having inferior cognitive abilities. In this context, some positive peculiarities of the children with these kind of impairments should be taken into account. Like, for example, Todorova (2016) found higher creativity levels in students with dyslexia. All possible strengths should be used for promoting and facilitating the healthy and harmonious personal development of students with SLD. That is why the research in this field is extremely important for promoting social inclusion and for the full realization of the potential of children with SLD. Although, in order to fully validate this indicator, it is necessary to expand the research with students with SLD into other countries to further expand our knowledge about the processes arising from the socialization of students with SLD (in general) and to find ways to facilitate their participation in school life.

\section{References}

(NJCLD), N. J. (2018). National Joint Committee for Learning Disabilities: Implications for Policy Regarding Research and Practice. Full report. USA.

Bardov, I. (2008). Eksperimentalna psikhologiya. Vtora chast [Experimental psychology. Part two]. Sofiya: Universitetsko izdatelstvo „Sv. Kliment Okhridski“.

Eriksŭn, E. (2013). Identichnost: mladost $i$ kriza [Identity: youth and crisis]. Sofiya: Riva.

Gallagher, A., Galvin, R., Robinson, K., Murphy, C.-A., Conway, P., \& Perry, A. (2020). The characteristics, life circumstances and self-concept of 13 year olds with and without disabilities in Ireland: A secondary analysis of the Growing Up in Ireland (GUI) study. PLoS ONE, 15(3): e0229599. doi:10.1371/0229599

Gribanov, A., \& Rysina, N. (March 2011). Osobennosti povedencheskogo reagirovaniya u detey s diskal'kuliyey [Features of behavioral response in children with dyscalculia]. Ekologiya detstvo. Ekologiya cheloveka, 7, 76-86.

Hammil, D. (February 1990). On defining learning disabilities: An emerging consensus. Journal of Learning Disabilities, 23 , 74-84. doi:10.1177/002221949002300201

Kaplan, R., \& Sakŭzo, D. (2013). Psikhologichesko testirane. Printsipi, prilozheniya i problemi. Sedmo izdanie [Psychological testing. Principles, applications and problems. Seventh edition.]. Sofiya: Iztok-Zapad.

Kaukiainen, A., Salmivalli, C., Lagerspetz, K., Tamminen, M., Vauras, M., Mäki, H., \& Poskiparta, E. (2002). Learning difficulties, social intelligence, and self-concept: Connections to bully-victim problems. Scandinavian Journal of Psychology, 43, 269-278. doi:10.1111/1467-9450.00295

Kevan, F. (2003). Challenging behavior and communication difficulties. British Journal of Learning Disabilities, 31, 75-80. doi:10.1046/j.1468-3156.2003.00226.x 
Kiseleva, N. (2011). Izucheniye struktury sotsial'nogo intellekta u uchashchikhsya s nesformirovannost'yu chitatel'skoy deyatel'nosti [Study of the structure of social intelligence in students with an unformed reading activity]. Moskva: Spetsial'noye obrazovaniye №3.

Kokoshkarova, A. (1984). Psikhologichno izsledvane na lichnostta v klinichnata praktika [Psychological study of personality in clinical practice]. Sofiya: Meditsina i fizkultura.

Levterova, D. (2005). Konsultirane pri obuchitelni trudnosti [Consulting learning difficulties]. Plovdiv: Universitetsko izdatelstvo "Paisii Khilendarski".

Levterova, D., Atanasova, Z., \& Trichkov, I. (2016). Strategii za rabota s detsa i uchenitsi sŭs spetsialni obrazovatelni potrebnosti [Strategies for working with children and students with special educational needs]. Plvdiv: Universitet 'sko izdatelstvo „Paisiü Khilendarski“.

Levterova, D., Atanasova, Z., Trichkov, I., Kostova, Z., \& Sivakova, V. (2018). Psikhologiya na detsa i uchenitsi sŭs spetsialni obrazovatelni potrebnosti [Psychology of children and students with special educational needs]. Plovdiv: Universitet·sko izdatelstvo „Paisiı̌ Khilendarski“.

Matanova, V. (2003). Psikhologiya na anomalnoto razvitie [Psychology of abnormal development]. Sofiya: Nemezida. Passolunghi, M. (2011). Cognitive and Emotional Factors in Children with Mathematical Learning Disabilities. International Journal of Disability, Development and Education., 58(1), 61-73.

Popzlateva, T. (2010). Choveshkata glukhota - sotsio-kulturna identichnost i profili na lichnostta [Human deafness - sociocultural identity and personality profiles]. Sofiya: Es print.

Prishchepova, I. (2019). Dizorfografiya mladshikh shkol'nikov [Dysorphography of primary students]. Sankt Peterburg: SPB: Karo.

Rodzhŭrs, K. (2018). Izrastvaneto na lichnostta. Vŭzgledŭt na edin terapevt za psikhoterapiyata. [On becoming a person. A therapist's view of psychotherapy.]. Sofiya: Iztok-Zapad.

Ruegg, E. (2006). Social skills in children with learning disabilities: using psychotherapy in the classroom. Annals of the American Psychotherapy Association, 9(3), 14-21.

Sorokin, V. (2003). Spetsial'naya psikhologiya [Special psychology]. Sankt Peterburg: Institut spetsial'noy pedagogiki i psikhologii.

Todorova, E. (2016). Disleksiya. Spetsifichni narusheniya na sposobnostta za uchene [Dyslexia. Specific learning disabilities]. Sofiya: Nov bŭlgarski universitet.

Vasileva, N. (2018). Detska nevropsikhologiya [Child neuropsychology]. Sofiya: Universitetsko izdatelstvo „Sv. Kliment Okhridski “.

Venkatesan, S., \& Lokesh, L. (2019). Impulsivity in students with specific learning disabilities. The International Journal of Indian Psychology, 7(4), 37-47. doi:10.25215/0704.005 